\title{
Methanofollis ethanolicus sp. nov., an ethanol- utilizing methanogen isolated from a lotus field
}

\author{
Correspondence \\ Hiroyuki Imachi \\ imachi@jamstec.go.jp
}

\author{
Hiroyuki Imachi, ${ }^{1}$ Sanae Sakai, ${ }^{1}$ Hiroyuki Nagai, ${ }^{2}$ Takashi Yamaguchi $^{2}$ \\ and Ken Takai ${ }^{1}$
}
${ }^{1}$ Subground Animalcule Retrieval (SUGAR) Program, Extremobiosphere Research Center, Japan Agency for Marine-Earth Science and Technology (JAMSTEC), Yokosuka, Kanagawa 237-0061, Japan
${ }^{2}$ Department of Environmental Systems Engineering, Nagaoka University of Technology, Nagaoka, Niigata 940-2188, Japan

\begin{abstract}
A novel methane-producing archaeon, designated strain $\mathrm{HASU}^{\top}$, was isolated from a lotus field. Cells were Gram-negative, non-motile, irregular cocci, 2-3 $\mu \mathrm{m}$ in diameter, and occurred singly. Growth was observed at $15-40{ }^{\circ} \mathrm{C}$ (optimum, $37^{\circ} \mathrm{C}$ ) and $\mathrm{pH}$ 6.5-7.5 (optimum, pH 7.0). The $\mathrm{G}+\mathrm{C}$ content of the genomic DNA was $60.9 \mathrm{~mol} \%$. Strain $\mathrm{HASU}^{\top}$ utilized ethanol, 1-propanol, 1 -butanol, hydrogen and formate for growth and methane production. It converted ethanol to methane and acetate. Based on comparative 16S rRNA gene sequence analysis, strain $\mathrm{HASU}^{\top}$ was shown to be affiliated with the genus Methanofollis. It was related most closely to the type strain of Methanofollis liminatans (96.1\% 16S rRNA gene sequence similarity). Based on phylogenetic analysis and phenotypic characteristics, strain $\mathrm{HASU}^{\top}$ is considered to represent a novel species of the genus Methanofollis, for which the name Methanofollis ethanolicus sp. nov. is proposed. The type strain is $\mathrm{HASU}^{\top}\left(=\mathrm{NBRC} 104120^{\top}=\mathrm{JCM}^{15103^{\top}}=\mathrm{DSM} 21041^{\top}\right)$.
\end{abstract}

Widdel (1986) described the first methane-producing archaea (methanogens) that were able to utilize alcohols other than methanol as substrates for growth and methane production. Two strains that were able to grow on secondary alcohols such as 2-propanol and 2-butanol were isolated, and one of these strains, designated strain $\mathrm{CV}^{\mathrm{T}}$, was also able to utilize ethanol as an energy source (Widdel, 1986). Strain $\mathrm{CV}^{\mathrm{T}}$ was subsequently characterized taxonomically and was described as representing Methanogenium organophilum (Widdel et al., 1988). At the time of writing, although several different taxonomic groups of methanogens have been shown to be capable of growth on secondary alcohols (Grahame \& Stadtman, 1993), Methanogenium organophilum is the only methanogen that is known to be able to grow with primary alcohols other than methanol. Recently, we have successfully isolated an ethanol-utilizing methanogen, designated strain $\mathrm{HASU}^{\mathrm{T}}$, from a lotus field. In the present report, we provide details of the morphological, physiological and phylogenetic characteristics of strain $\mathrm{HASU}^{\mathrm{T}}$ and propose that this strain represents a novel species of the genus Methanofollis. This novel taxon is the second example of a methanogen that is capable of utilizing primary alcohols for growth and methane production.

The GenBank/EMBL/DDBJ accession number for the 16S rRNA gene sequence of strain $\mathrm{HASU}^{\top}$ is $\mathrm{AB} 371073$.
A lotus field mud sample was obtained at Nagaoka,

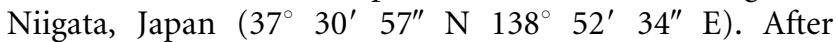
sampling, the mud was immediately washed with phosphate buffer $(10 \mathrm{mM}, \mathrm{pH} 7.2)$ under nitrogen gas to remove extra roots and plant debris, and the mud was then collected by centrifugation for $5 \mathrm{~min}$ at $9000 \mathrm{~g}$. The mud was resuspended in phosphate buffer and inoculated into an enrichment culture medium. The medium for cultivation of strain $\mathrm{HASU}^{\mathrm{T}}$ was based on that of Widdel \& Pfennig (1981). The medium consisted of the following components (per litre distilled water): $0.54 \mathrm{~g} \mathrm{NH}_{4} \mathrm{Cl}$, $0.14 \mathrm{~g} \mathrm{KH}_{2} \mathrm{PO}_{4}, 0.2 \mathrm{~g} \mathrm{MgCl}_{2} .6 \mathrm{H}_{2} \mathrm{O}, 0.15 \mathrm{~g} \mathrm{CaCl}_{2} .2 \mathrm{H}_{2} \mathrm{O}$, $2.5 \mathrm{~g} \mathrm{NaHCO}_{3}, 0.3 \mathrm{~g} \mathrm{Na}_{2} \mathrm{~S} .9 \mathrm{H}_{2} \mathrm{O}, 0.3 \mathrm{~g}$ cysteine $\cdot \mathrm{HCl}, 1 \mathrm{ml}$ trace element solution, $1 \mathrm{ml}$ vitamin solution and $1 \mathrm{ml}$ resazurin solution $\left(1 \mathrm{mg} \mathrm{ml}^{-1}\right)$. The trace element solution contained (per litre distilled water): $1.27 \mathrm{~g}$ $\mathrm{FeCl}_{2} .4 \mathrm{H}_{2} \mathrm{O}, 0.2 \mathrm{~g} \mathrm{MnCl}_{2} .4 \mathrm{H}_{2} \mathrm{O}, 0.13 \mathrm{~g} \mathrm{CoCl}_{2}, 0.14 \mathrm{~g}$ $\mathrm{ZnCl}_{2}, 0.001 \mathrm{~g} \mathrm{CuCl}_{2} .2 \mathrm{H}_{2} \mathrm{O}, 0.01 \mathrm{~g} \mathrm{AlCl}_{3}, 0.006 \mathrm{~g} \mathrm{H}_{3} \mathrm{BO}_{3}$, $0.02 \mathrm{~g} \mathrm{Na}_{2} \mathrm{MoO}_{4} \cdot 2 \mathrm{H}_{2} \mathrm{O}, 0.01 \mathrm{~g} \mathrm{NiCl}_{2}, 0.002 \mathrm{~g} \mathrm{Na}_{2} \mathrm{SeO}_{3}$ and $0.003 \mathrm{~g} \mathrm{Na}_{2} \mathrm{WO}_{4} \cdot 2 \mathrm{H}_{2} \mathrm{O}$. The vitamin solution was composed of the following vitamins (per litre distilled water): $4.9 \mathrm{mg}$ biotin, $8.8 \mathrm{mg}$ folic acid, $4.1 \mathrm{mg}$ pyridoxine $\cdot \mathrm{HCl}, 6.7 \mathrm{mg}$ thiamine $\cdot \mathrm{HCl}, 7.5 \mathrm{mg}$ riboflavin, $2.4 \mathrm{mg}$ nicotinic acid, $9.5 \mathrm{mg}$ D-pantothenate (calcium salt), $0.1 \mathrm{mg}$ vitamin $\mathrm{B}_{12}, 2.7 \mathrm{mg}$ p-aminobenzoic acid and $4.1 \mathrm{mg}$ lipoic acid. Enrichment cultures were incubated anaerobically at $25^{\circ} \mathrm{C}$. After isolation, all incubations were performed at $37^{\circ} \mathrm{C}$ in $50-\mathrm{ml}$ serum vials containing $20 \mathrm{ml}$ 
medium ( $\mathrm{pH} 7.2$ at $25{ }^{\circ} \mathrm{C}$ ) under an atmosphere of $\mathrm{N}_{2} /$ $\mathrm{CO}_{2}$ (80:20, by vol.) without shaking, unless otherwise mentioned. The serum vials were sealed with butyl rubber stoppers and aluminium crimp seals. To monitor whether the media were kept under anaerobic conditions, resazurin was added to the medium as a redox indicator. In the nutritional tests, substrates added to the vials were neutralized prior to inoculation, and the media were supplemented with $0.01 \%$ yeast extract $(\mathrm{w} / \mathrm{v})$ and $1 \mathrm{mM}$ acetate. Growth and substrate utilization were determined by monitoring the turbidity of the cultures (OD at $400 \mathrm{~nm}$ ) and the production of methane. All incubations for growth/substrate utilization tests were performed in triplicate at $37{ }^{\circ} \mathrm{C}$ for over 3 months. Effects of temperature, $\mathrm{pH}, \mathrm{NaCl}$ concentration and antibiotics on the growth of strain $\mathrm{HASU}^{\mathrm{T}}$ were determined in media containing $0.01 \%$ yeast extract $(\mathrm{w} / \mathrm{v})$ in the presence of $5 \mathrm{mM}$ ethanol in triplicate culture vessels. Tests for growth temperature, $\mathrm{pH}$ and salinity ranges were carried out at 4$60{ }^{\circ} \mathrm{C}, \mathrm{pH} 5.5-8.5$ and $1-30 \mathrm{~g} \mathrm{NaCl} 1^{-1}$. For $\mathrm{pH}$ growth tests, the $\mathrm{pH}$ value was adjusted at room temperature to $5.5-8.5$ by adding $\mathrm{HCl}$ or $\mathrm{NaOH}$ solution under a $100 \%$ $\mathrm{N}_{2}$ atmosphere prior to inoculation. The $\mathrm{pH}$ of the medium was monitored every 5 days by using a handytype $\mathrm{pH}$ meter (HORIBA Twin $\mathrm{pH} \mathrm{B-212)}$, and the $\mathrm{pH}$ was readjusted by using $\mathrm{HCl}$ and $\mathrm{NaOH}$ solution if it had changed significantly from the initial value. To test for the effect of $\mathrm{NaCl}$ concentration on growth, $\mathrm{NaCl}$ was added to the medium at concentrations of $1-30 \mathrm{~g} \mathrm{l}^{-1}$. Antibiotic susceptibility was examined with cultures supplemented with antibiotics at a final concentration of $100 \mu \mathrm{g} \mathrm{ml}^{-1}$.

Cell morphology was examined under an epifluorescence microscope (Olympus BX51F) with a colour CCD camera system (Olympus DP71). The Gram-staining reaction was performed according to Hucker's method (Doetsch, 1981). Cell lysis was checked by adding SDS at a final concentration of $0.01-1.0 \%(\mathrm{w} / \mathrm{v})$, and was determined by microscopic observation of cell integrity. Short-chain fatty acids, methane, hydrogen and carbon dioxide were measured as described by Imachi et al. (2000, 2002). Ethanol was measured by HPLC by using an SCR-101-H column (Shimadzu) and a refractive index detector (Sekiguchi et al., 2001). The $G+C$ content of the genomic DNA was determined by HPLC as described by Nakagawa et al. (2003), and represented the result of a single determination.

All procedures for DNA extraction, 16S rRNA gene-based cloning and sequencing were as reported previously (Imachi et al., 2006). For PCR amplification, primers Arch21F (DeLong, 1992) and 1490R (Weisburg et al., 1991) were used to obtain the nearly full-length $16 \mathrm{~S}$ rRNA gene sequence of strain $\mathrm{HASU}^{\mathrm{T}}$. Comparative $16 \mathrm{~S}$ rRNA gene sequence phylogenetic analysis was performed as described previously (Imachi et al., 2006). 16S rRNA gene sequence similarity values were calculated by using the Calculate Matrix function of the ARB program with Jukes and Cantor correction (Jukes \& Cantor, 1969; Ludwig et al., 2004). Bootstrap resampling analysis was performed with the neighbour-joining, maximum-parsimony and maximum-likelihood methods to estimate the confidence of tree topologies, as described by Sekiguchi et al. (2006).

To cultivate ethanol-utilizing methanogens, the initial enrichment medium containing $5 \mathrm{mM}$ ethanol as an energy source, $0.01 \%$ yeast extract $(w / v)$ and three antibiotics (vancomycin, penicillin $\mathrm{G}$ and kanamycin at a concentration of $100 \mu \mathrm{g} \mathrm{ml}^{-1}$ ) was used. The enrichment culture was incubated anaerobically at $25^{\circ} \mathrm{C}$. Cell growth and methane formation were observed after approximately 6 months incubation in the initial enrichment culture, but growth and methane production were detected within 1420 days incubation in subsequent cultures ( $5 \%$ inoculum, $\mathrm{v} / \mathrm{v})$ at $25{ }^{\circ} \mathrm{C}$. Microscopic observation showed that irregularly coccoid, $\mathrm{F}_{420}$-autofluorescent cells were dominant in the ethanol enrichment culture. After successive transfers, the roll-tube method was employed three times. However, colony formation was not observed after 3 months incubation. Purification of the methanogen was by a serial dilution-to-extinction technique in liquid medium containing $5 \mathrm{mM}$ ethanol, vancomycin, penicillin $\mathrm{G}$ and kanamycin. The purity of strain $\mathrm{HASU}^{\mathrm{T}}$ was demonstrated by the failure to grow in the following media at 25,37 or $55^{\circ} \mathrm{C}$ : (i) thioglycollate medium (Difco) containing approximately $150 \mathrm{kPa} \mathrm{H}_{2} / \mathrm{CO}_{2}$ (in the head space) and $10 \mathrm{mM}$ sulphate; (ii) thioglycollate medium containing $5 \mathrm{mM}$ ethanol and $10 \mathrm{mM}$ sulphate; (iii) thioglycollate medium containing $10 \mathrm{mM}$ sucrose, $10 \mathrm{mM}$ glucose, $10 \mathrm{mM}$ cellobiose and $10 \mathrm{mM}$ xylose; and (iv) AC medium (Difco). Moreover, we also tested purity by using a $16 \mathrm{~S}$ rRNA gene-based cloning analysis with the archaeal universal primer set Ar109f (Großkopf $e t$ al., 1998) and 1490R. Forty-eight clones were selected randomly and sequenced. All 48 clonal sequences were identical and had the same $16 \mathrm{~S}$ rRNA gene sequence as strain $\mathrm{HASU}^{\mathrm{T}}$. We evaluated purity based on the failure to

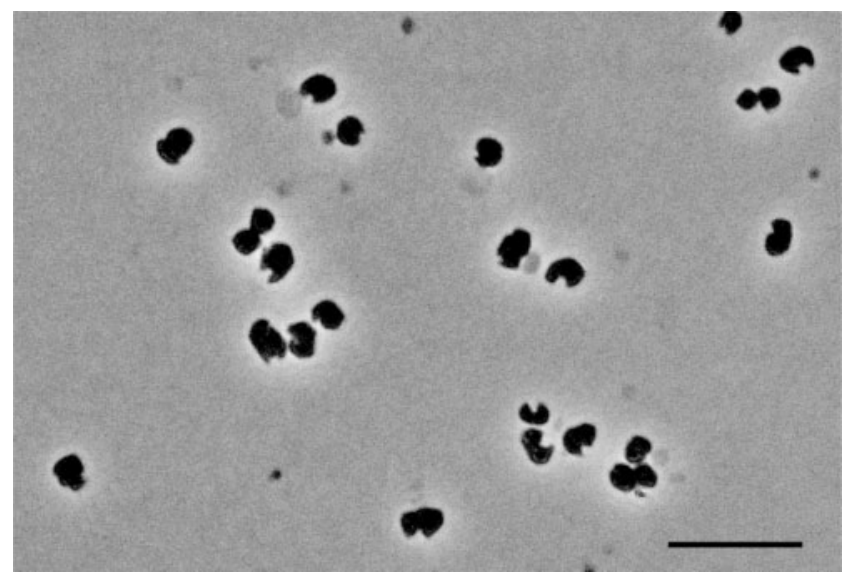

Fig. 1. Phase-contrast micrograph of cells of strain $\mathrm{HASU}^{\top}$ grown on $5 \mathrm{mM}$ ethanol medium supplemented with $0.01 \%$ yeast extract (w/v). Bar, $10 \mu \mathrm{m}$. 


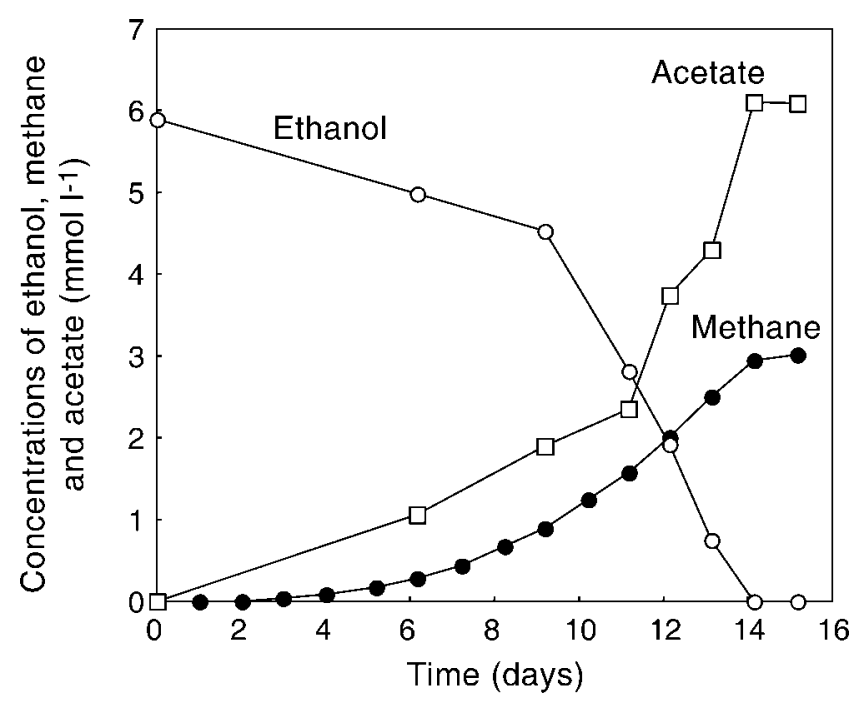

Fig. 2. Methane and acetate production from ethanol by strain $\mathrm{HASU}^{\top}$. Cultivation was performed at $37^{\circ} \mathrm{C}$. The experiments were repeated twice and gave similar results.

recover bacterial $16 \mathrm{~S}$ rRNA gene amplifications by PCR with a universal bacterial primer set EUB338* (Amann et al., 1990; Daims et al., 1999) and 1490R. The results of these molecular surveys also indicated that the culture of strain $\mathrm{HASU}^{\mathrm{T}}$ was axenic.

Cells of strain $\mathrm{HASU}^{\mathrm{T}}$ were Gram-negative, non-motile, irregular cocci, 2-3 $\mu \mathrm{m}$ in diameter, that occurred singly (Fig. 1). Cells were susceptible to lysis with $0.1 \%$ SDS $(\mathrm{w} / \mathrm{v})$, suggesting the presence of a proteinaceous cell wall (Boone \& Whitman, 1988). The strain was strictly anaerobic given that its growth was completely inhibited in the presence of trace quantities of oxygen $(0.1$ and $0.2 \%$ $\left.\mathrm{O}_{2}, \mathrm{v} / \mathrm{v}\right)$. Strain $\mathrm{HASU}^{\mathrm{T}}$ required acetate as carbon source for growth on substrates other than ethanol. Yeast extract was not required for growth, but it did stimulate growth. Interestingly, in ethanol medium in the absence of yeast extract, cells of strain $\mathrm{HASU}^{\mathrm{T}}$ formed floc-like aggregates. Ethanol (5 mM), 1-propanol (5 mM), 1-butanol (5 mM), $\mathrm{H}_{2}$ (approximately $150 \mathrm{kPa}$ in the head space) or formate (40 $\mathrm{mM})$ supported growth and methane production as the sole energy source. In ethanol medium, ethanol was converted to methane and acetate stoichiometrically, which is explained by the equation $2 \mathrm{CH}_{3} \mathrm{CH}_{2} \mathrm{OH}+\mathrm{HCO}_{3}{ }^{-}$ $\rightarrow \mathrm{CH}_{4}+2 \mathrm{CH}_{3} \mathrm{COO}^{-}+\mathrm{H}_{2} \mathrm{O}+\mathrm{H}^{+}$(Fig. 2). The end products from 1-propanol were methane and propionate. The following substrates did not support growth or methane production: pyruvate $(20 \mathrm{mM})$, lactate $(20 \mathrm{mM})$, acetate $(20 \mathrm{mM})$, propionate $(20 \mathrm{mM})$, trimethylamine $(10 \mathrm{mM})$, dimethylamine $(10 \mathrm{mM})$, methylamine $(10 \mathrm{mM})$, cyclopen-

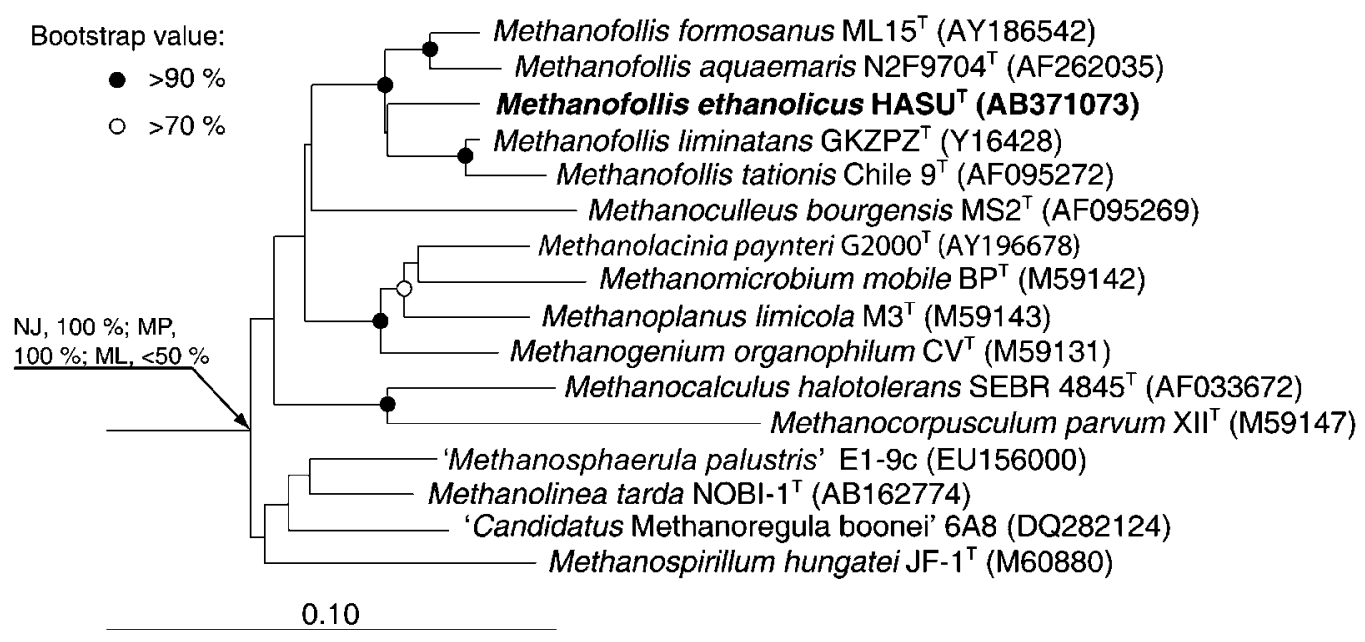

Fig. 3. Phylogenetic tree based on comparative analyses of $16 \mathrm{~S}$ rRNA gene sequences, showing the position of strain $\mathrm{HASU}^{\top}$ among members of the order Methanomicrobiales. The tree was constructed based on a distance matrix analysis of 16S rRNA gene sequences (neighbour-joining tree). 16S rRNA gene sequences of three strains belonging to the class Thermoplasmata [Picrophilus oshimae KAW2/2 ${ }^{\top}$ (GenBank accession no. X84901), clone WCHD3-02 (AF050616) and clone pMC2A24 (AB019736)] were used to root the tree (not shown). Branching points supported by bootstrap percentages above $90 \%$ by all three analysis methods [based on 1000 replicates, estimated by using the neighbour-joining (NJ), maximum-parsimony (MP) and maximum-likelihood (ML) methods] are indicated by solid circles, and nodes with open circles indicate $>70 \%$ bootstrap support by the three analyses. The accession number of each reference sequence is shown in parentheses. Bar, 0.1 nucleotide changes per sequence position. 
tanol $(20 \mathrm{mM})$, methanol $(20 \mathrm{mM})$, 2-propanol (5 mM) and 2-butanol (5 mM).

The optimum growth temperature of strain $\mathrm{HASU}^{\mathrm{T}}$ was $37^{\circ} \mathrm{C}$, although the first enrichment culture was incubated at $25{ }^{\circ} \mathrm{C}$. No growth occurred below $10{ }^{\circ} \mathrm{C}$ or above $42{ }^{\circ} \mathrm{C}$ over 3 months incubation. The $\mathrm{pH}$ range for growth was estimated to be 6.5-7.5, with optimum growth at $\mathrm{pH} 7.0$. Under optimum conditions ( $\left.\mathrm{pH} 7.0,37^{\circ} \mathrm{C}\right)$, the doubling time on ethanol medium containing $0.01 \%$ yeast extract $(\mathrm{w} / \mathrm{v})$ was 3.0 days, which was calculated based on measurement of the optical density at $400 \mathrm{~nm}$. Strain $\mathrm{HASU}^{\mathrm{T}}$ did not require $\mathrm{NaCl}$ for growth, but it was able to grow at $\mathrm{NaCl}$ concentrations up to $25 \mathrm{~g} \mathrm{l}^{-1}$. Strain $\mathrm{HASU}^{\mathrm{T}}$ was resistant to ampicillin, vancomycin, penicillin $G$ and kanamycin. Rifampicin, neomycin and chloramphenicol completely inhibited growth.

The G $+\mathrm{C}$ content of the total DNA of strain $\mathrm{HASU}^{\mathrm{T}}$ was $60.9 \mathrm{~mol} \%$. The nearly complete $16 \mathrm{~S}$ rRNA gene sequence (1396 bp) of strain HASU $^{\mathrm{T}}$ was determined. Comparative $16 \mathrm{~S}$ rRNA gene sequence analysis showed that strain $\mathrm{HASU}^{\mathrm{T}}$ was affiliated with the genus Methanofollis (Fig. 3). The closest relative of strain $\mathrm{HASU}^{\mathrm{T}}$ was Methanofollis liminatans GKZPZ ${ }^{\mathrm{T}}(96.1 \%$ 16S rRNA gene sequence similarity; Fig. 3) (Zellner et al., 1990, 1999).
Based on its morphological, physiological and molecular phylogenetic traits, strain $\mathrm{HASU}^{\mathrm{T}}$ is considered to belong within the genus Methanofollis. As shown in Table 1, strain $\mathrm{HASU}^{\mathrm{T}}$ and members of the genus Methanofollis share several phenotypic features, for example cell morphology, DNA G + C content, growth temperature and $\mathrm{pH}$ range (Table 1). However, strain HASU $^{\mathrm{T}}$ was able to utilize primary alcohols (ethanol, 1-propanol and 1-butanol), in contrast to recognized members of the genus Methanofollis. In addition, levels of $16 \mathrm{~S}$ rRNA gene sequence similarity also suggest that strain $\mathrm{HASU}^{\mathrm{T}}$ is distinct from recognized species of the genus Methanofollis (Stackebrandt \& Goebel, 1994; Keswani \& Whitman, 2001).

Strain $\mathrm{HASU}^{\mathrm{T}}$ converted ethanol to methane and acetate. This reaction was also observed for Methanofollis organophilum, an ethanol-utilizing methanogen. This might imply that strain $\mathrm{HASU}^{\mathrm{T}}$ and Methanofollis organophilum share a similar metabolic pathway for methanogenesis from ethanol. However, as the pattern of secondary alcohol utilization is different between these two methanogens (Table 1), the metabolic pathway for alcohol degradation may also be different for the two taxa. From the taxonomic point of view, strain $\mathrm{HASU}^{\mathrm{T}}$ can be phylogenetically distinguished from the type strain of Methanofollis organophilum (16S rRNA gene sequence similarity of $92.1 \%$; Fig. 3 ).

Table 1. Differential characteristics between strain $\mathrm{HASU}^{\top}$ (Methanofollis ethanolicus sp. nov.), other members of the genus Methanofollis and Methanogenium organophilum

Strains: 1, HASU ${ }^{\mathrm{T}}$ (data from the present study); 2, Methanofollis tationis Chile $9^{\mathrm{T}}$ (Zabel et al., 1984; Zellner et al., 1999; Zellner \& Boone, 2001); 3 , Methanofollis liminatans $\mathrm{GKZPZ}^{\mathrm{T}}$ (Zellner et al., 1990, 1999; Zellner \& Boone, 2001); 4, Methanofollis aquaemaris N2F9704 ${ }^{\mathrm{T}}$ (Lai \& Chen, 2001; Wu et al., 2005); 5, Methanofollis formosanus $\mathrm{ML}^{\mathrm{T}}{ }^{\mathrm{T}}$ (Wu et al., 2005); 6, Methanogenium organophilum $\mathrm{CV}^{\mathrm{T}}$ (Widdel, 1986; Widdel et al., 1988). + , Positive; - , negative; $+/-$, variable; $(+)$, growth and methane production very poor; ND, not determined.

\begin{tabular}{|c|c|c|c|c|c|c|}
\hline Characteristic & 1 & 2 & 3 & 4 & 5 & 6 \\
\hline $\begin{array}{l}\text { DNA G + C content } \\
(\mathrm{mol} \%)\end{array}$ & 60.9 & $54^{\star}$ & 60 & 59.1 & 58.4 & $46.7^{\star}$ \\
\hline $\begin{array}{l}\text { Optimum temperature } \\
\text { (range) }\left({ }^{\circ} \mathrm{C}\right)\end{array}$ & $37(15-40)$ & $37-40(25-45)$ & $40(25-44)$ & $37(20-43)$ & $37(20-42)$ & $30-35$ \\
\hline Optimum pH (range) & $7(6.5-7.5)$ & $7(6.3-8.8)$ & 7 & $6.5(6.3-8.0)$ & $6.6(5.6-7.3)$ & $6.4-7.3$ \\
\hline $\begin{array}{l}\text { Optimum } \mathrm{NaCl} \text { (range) } \\
\left(\mathrm{g} \mathrm{l}^{-1}\right)\end{array}$ & $0(0-25)$ & $8-12$ & $0(0-35)$ & $5(0-6)$ & $3(0-4)$ & 20 \\
\hline Motility & - & $+1-$ & + & - & - & - \\
\hline \multicolumn{7}{|l|}{ Substrate utilization } \\
\hline Ethanol & + & - & - & - & - & + \\
\hline \multicolumn{7}{|l|}{ Growth requirement } \\
\hline Yeast extract & - & + & - & - & + & - \\
\hline Acetate & $+\dagger$ & + & ND & - & - & $+\dagger$ \\
\hline
\end{tabular}

${ }^{\star}$ Determined by thermal denaturation.

$\dagger$ Acetate is required as carbon source for growth on substrates other than ethanol. 
Based on these phenotypic and phylogenetic properties, we suggest that strain HASU $^{\mathrm{T}}$ represents a novel species of the genus Methanofollis, for which the name Methanofollis ethanolicus sp. nov. is proposed.

\section{Description of Methanofollis ethanolicus sp. nov.}

Methanofollis ethanolicus (e.tha.no'li.cus. N.L. n. ethanol ethanol; L. suf. -icus $-a-u m$ suffix used with various meanings; N.L. masc. adj. ethanolicus belonging to ethanol, referring to the substrate ethanol, which can be metabolized by the species).

Strictly anaerobic. Cells stain Gram-negative, are nonmotile, irregular cocci, $2-3 \mu \mathrm{m}$ in diameter, and are resistant to lysis with $<0.1 \%$ SDS (w/v). $\mathrm{H}_{2}$, formate, ethanol, 1-propanol and 1-butanol can be used for growth and methane production. Secondary alcohols (2-propanol, 2-butanol and cyclopentanol) are not utilized. Acetate is required as carbon source for growth on substrates other than ethanol. Yeast extract enhances growth. Temperature range for growth is $15-40{ }^{\circ} \mathrm{C}$ (optimum, $37^{\circ} \mathrm{C}$ ). $\mathrm{pH}$ range for growth is 6.5-7.5 (optimum, $\mathrm{pH} 7.0$ ). Growth occurs in the presence of $0-2.5 \% \mathrm{NaCl}$ but does not occur in the presence of $3.0 \% \mathrm{NaCl}$. The $\mathrm{G}+\mathrm{C}$ content of the DNA of the type strain is $60.9 \mathrm{~mol} \%$ (HPLC).

The type strain, HASU $^{\mathrm{T}} \quad\left(=\mathrm{NBRC} \quad 104120^{\mathrm{T}}=\mathrm{JCM}\right.$ $15103^{\mathrm{T}}=$ DSM $21041^{\mathrm{T}}$ ), was isolated from lotus field mud at Nagaoka, Niigata, Japan. Related most closely to Methanofollis liminatans $\mathrm{GKZPZ}^{\mathrm{T}}$ (96.1\% 16S rRNA gene sequence similarity).

\section{Acknowledgements}

We thank Norika Meguro, Eiji Tasumi and Masayuki Miyazaki at JAMSTEC for their technical assistance. We also thank Ryoko Taniguchi at the Nagaoka University of Technology for her assistance with ethanol measurements, and Hidenobu Takahashi at Ohguchi Lotus Productive Society for his assistance with sampling in the field. This research was partly supported by grants from the Ministry of Education, Culture, Sports, Science and Technology, Japan, the Japan Society for the Promotion of Science, and the Institute for Fermentation, Osaka.

\section{References}

Amann, R. I., Binder, B. J., Olson, R. J., Chisholm, S. W., Devereux, R. \& Stahl, D. A. (1990). Combination of $16 \mathrm{~S}$ rRNA-targeted oligonucleotide probes with flow cytometry for analyzing mixed microbial populations. Appl Environ Microbiol 56, 1919-1925.

Boone, D. R. \& Whitman, W. B. (1988). Proposal of minimal standards for describing new taxa of methanogenic bacteria. Int J Syst Bacteriol 38, 212-219.

Daims, H., Brühl, A., Amann, R., Schleifer, K. H. \& Wagner, M. (1999). The domain-specific probe EUB338 is insufficient for the detection of all Bacteria: development and evaluation of a more comprehensive probe set. Syst Appl Microbiol 22, 434-444.

DeLong, E. F. (1992). Archaea in coastal marine environments. Proc Natl Acad Sci U S A 89, 5685-5689.
Doetsch, R. N. (1981). Determinative methods of light microscopy. In Manual of Methods for General Bacteriology, pp. 21-33. Edited by P. Gerhardt, R. G. E. Murray, R. N. Costilow, E. W. Nester, W. A. Wood, N. R. Krieg \& G. H. Phillips. Washington, DC: American Society for Microbiology.

Grahame, D. A. \& Stadtman, T. C. (1993). Redox enzymes of methanogens: physicochemical properties of selected, purified oxidoreductases. In Methanogenesis, pp. 335-359. Edited by J. G. Ferry. New York: Chapman \& Hall.

Großkopf, R., Janssen, P. H. \& Liesack, W. (1998). Diversity and structure of the methanogenic community in anoxic rice paddy soil microcosms as examined by cultivation and direct $16 \mathrm{~S}$ rRNA gene sequence retrieval. Appl Environ Microbiol 64, 960-969.

Imachi, H., Sekiguchi, Y., Kamagata, Y., Ohashi, A. \& Harada, H. (2000). Cultivation and in situ detection of a thermophilic bacterium capable of oxidizing propionate in syntrophic association with hydrogenotrophic methanogens in a thermophilic methanogenic granular sludge. Appl Environ Microbiol 66, 3608-3615.

Imachi, H., Sekiguchi, Y., Kamagata, Y., Hanada, S., Ohashi, A. \& Harada, H. (2002). Pelotomaculum thermopropionicum gen. nov., sp. nov., an anaerobic, thermophilic, syntrophic propionate-oxidizing bacterium. Int J Syst Evol Microbiol 52, 1729-1735.

Imachi, H., Sekiguchi, Y., Kamagata, Y., Loy, A., Qiu, Y.-L., Hugenholtz, P., Kimura, N., Wagner, M., Ohashi, A. \& Harada, H. (2006). Non-sulfate-reducing, syntrophic bacteria affiliated with Desulfotomaculum cluster I are widely distributed in methanogenic environments. Appl Environ Microbiol 72, 2080-2091.

Jukes, T. H. \& Cantor, C. R. (1969). Evolution of protein molecules. In Mammalian Protein Metabolism, vol. 3, pp. 21-132. Edited by H. N. Munro. New York: Academic Press.

Keswani, J. \& Whitman, W. B. (2001). Relationship of $16 \mathrm{~S}$ rRNA sequence similarity to DNA hybridization in prokaryotes. Int J Syst Evol Microbiol 51, 667-678.

Lai, M.-C. \& Chen, S.-S. (2001). Methanofollis aquaemaris sp. nov., a methanogen isolated from an aquaculture fish pond. Int J Syst Evol Microbiol 51, 1873-1880.

Ludwig, W., Strunk, O., Westram, R., Richter, L., Meier, H., Yadhukumar, Buchner, A., Lai, T., Steppi, S. \& other authors (2004). ARB: a software environment for sequence data. Nucleic Acids Res 32, 1363-1371.

Nakagawa, S., Takai, K., Horikoshi, K. \& Sako, Y. (2003). Persephonella hydrogeniphila sp. nov., a novel thermophilic, hydrogen-oxidizing bacterium from a deep-sea hydrothermal vent chimney. Int J Syst Evol Microbiol 53, 863-869.

Sekiguchi, Y., Takahashi, H., Kamagata, Y., Ohashi, A. \& Harada, H. (2001). In situ detection, isolation, and physiological properties of a thin filamentous microorganism abundant in methanogenic granular sludges: a novel isolate affiliated with a clone cluster, the green nonsulfur bacteria, subdivision I. Appl Environ Microbiol 67, 5740-5749.

Sekiguchi, Y., Imachi, H., Susilorukmi, A., Muramatsu, M., Ohashi, A., Harada, H., Hanada, S. \& Kamagata, Y. (2006). Tepidanaerobacter syntrophicus gen. nov., sp. nov., an anaerobic, moderately thermophilic, syntrophic alcohol- and lactate-degrading bacterium isolated from thermophilic digested sludges. Int J Syst Evol Microbiol 56, 1621-1629.

Stackebrandt, E. \& Goebel, B. M. (1994). Taxonomic note: a place for DNA-DNA reassociation and $16 \mathrm{~S}$ rRNA sequence analysis in the present species definition in bacteriology. Int J Syst Bacteriol 44, 846-849.

Weisburg, W. G., Barns, S. M., Pelletier, D. A. \& Lane, D. J. (1991). $16 \mathrm{~S}$ ribosomal DNA amplification for phylogenetic study. J Bacteriol 173, 697-703.

Widdel, F. (1986). Growth of methanogenic bacteria in pure culture with 2-propanol and other alcohols as hydrogen donors. Appl Environ Microbiol 51, 1056-1062. 
Widdel, F. \& Pfennig, N. (1981). Studies on dissimilatory sulfatereducing bacteria that decompose fatty acids. I. Isolation of new sulfate-reducing bacteria enriched with acetate from saline environments. Description of Desulfobacter postgatei gen. nov., sp. nov. Arch Microbiol 129, 395-400.

Widdel, F., Rouvière, P. E. \& Wolf, R. S. (1988). Classification of secondary alcohol-utilizing methanogens including a new thermophilic isolate. Arch Microbiol 150, 477-481.

Wu, S.-Y., Chen, S.-S. \& Lai, M.-C. (2005). Methanofollis formosanus sp. nov., isolated from a fish pond. Int J Syst Evol Microbiol 55, 837842.

Zabel, H. P., König, H. \& Winter, J. (1984). Isolation and characterization of a new coccoid methanogen, Methanogenium tatii, spec. nov. from a solfataric field on Mount Tatio. Arch Microbiol 137, 308-315.
Zellner, G. \& Boone, D. R. (2001). Genus III. Methanofollis. In Bergey's Manual of Systematic Bacteriology, 2nd edn, vol. 1, pp. 253-255. Edited by D. R. Boone \& R. W. Castenholz. New York: Springer.

Zellner, G., Sleytr, U. B., Messner, P., Kneifel, H. \& Winter, J. (1990). Methanogenium liminatans spec. nov., a new coccoid, mesophilic methanogen able to oxidize secondary alcohols. Arch Microbiol 153, 287-293.

Zellner, G., Boone, D. R., Keswani, J., Whitman, W. B., Woese, C. R., Hagelstein, A., Tindall, B. J. \& Stackebrandt, E. (1999). Reclassification of Methanogenium tationis and Methanogenium liminatans as Methanofollis tationis gen. nov., comb. nov. and Methanofollis liminatans comb. nov. and description of a new strain of Methanofollis liminatans. Int J Syst Bacteriol 49, 247-255. 